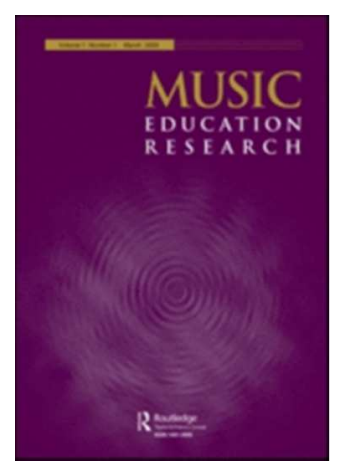

\title{
Songs are Taught, Songs are Learnt: Musical Preferences in Early Childhood
}

\begin{tabular}{|r|l|}
\hline Journal: & Music Education Research \\
\hline Manuscript ID & CMUE-2015-0058.R2 \\
\hline Manuscript Type: & Original Article \\
\hline Keywords: & $\begin{array}{l}\text { Musical Preferences, Learning Contexts, Musical Repertoire, Early } \\
\text { Childhood Education }\end{array}$ \\
\hline \multicolumn{2}{|c}{} \\
\hline
\end{tabular}

SCHOLARONE

Manuscripts 


\title{
Songs are Taught, Songs are Learnt: Musical Preferences in Early Childhood
}

\begin{abstract}
This study analyses the musical preferences of children in early childhood education. It also strives to determine the learning environment where these preferences develop, as well as to identify both teachers' and families' degree of knowledge of these preferences.

The study was conducted in four Spanish autonomous communities: the Basque Country, Cantabria, the Community of Valencia and the Balearic Islands. A total of 286 five-year-old children, their parents and their teachers

participated. The analytical design consisted of a three-fold interview through which we gathered and compared the information obtained.

The genres and sub-genres of music that the children prefer emerged from the analysis of the results, as well as the influence of each learning environment. Likewise, information is provided on the percentage of parents and teachers who are aware of the children's musical preferences.
\end{abstract}

Keywords: Musical Preferences, Learning Contexts, Musical Repertoire, Early Childhood Education.

\section{Introduction}

This study analyses the preferences and tastes of boys and girls five years of age while paying close attention to the environments in which this taste develops. According to Hargreaves, North and Tarrant (2006), the term "preference" refers to the selection of a musical piece from among others at a specific moment in time, and "taste" refers to a general pattern of individual preferences over longer time periods. Today, studies reveal that the vast majority of the songs preferred are popular, fashionable and usually simple with clear themes and progressions of chords which are resolved in direct, easily predictable ways (Levitin, 2006). They often come from the media, primarily screen-based media (television, cell phones and videogames). In addition, the evidence regarding preferred songs was investigated in the school and family environments to determine and assess the level of agreement among them.

In humans, an interest in music is a biological trait. Most individuals listen to music daily, whether passively or actively. Being musical is part of the human design (Mithen, 2009; Welch, 2005) in that our musical development begins before birth. Participating actively in listening to music sparks pleasure, brings reward and promotes a tendency towards a new use of musical activities that can be important to our physical and mental wellbeing (Blood \& Zatorre, 2001). For this reason, we believe that participating in engaging, positive experiences can lead children to want to experiment with new musical practices, and this contributes to shaping their musical taste. However, we listen to music in a multitude of different scenarios and circumstances, which enables music to play different roles in our lives and means that our tastes and preferences, even from infancy, are in constant flux (Hargreaves, North \& Tarrant, 2006). Musical preferences and its relation to music education have been widely studied (Dobrota \& Ercegovac, 2015; Hui, 2009)

According to Malbrán, Díaz and Mónaco (2013), the investigation of childhood musical taste and preferences contributes importantly to the study of aesthetic development, identity and group formation. Studies have been dedicated to describing the formation of musical taste, to preferred activities or experiences that include the active practice of music and to how musical taste can be generated or modified during early childhood (Peery \& Peery, 1986; Schuckert \& McDonald, 1968). The development of taste and preferences can be addressed from various perspectives, for example, experimental aesthetics, 
development and the theory of social identity. The process of forming musical taste is influenced by characteristics particular to the listener, the music and the context in which the music is listened to. It is possible to specify how these factors interact such that a musical preference emerges that over time can become a specific pattern of the subject's musical taste. The immediate responses of individuals who listen to music in terms of patterns of musical style or genre can be more influential and can condition how one listens to specific music more than the musical piece itself (North \& Hargreaves, 1997). The listener's own characteristics, for example, age, musical training, knowledge or experience, also condition musical listening. The responses to these musical stimuli follow certain conventional modes related to the children's enculturation (Malbrán, 2010). This enculturation, or acculturation as Hargreaves (1998) calls it, is related to children's spontaneous musical development and is associated not only with physical and cognitive maturity but also with their everyday experiences of socialization, that is, with their belonging to a given culture. Tanner, Asbridge and Wortley (2008) found that musical preferences are varied and structured, associated with the forms and degrees of participation in the activity of groups at the same level. In young students, relationships have been found between the children's cultural context and their preferences with regard to musical activities in the music classroom (Yim \& Ebbeck, 2009). Likewise, the immediate situation and social or institutional context in which they listen to music also defines and shapes the responses to a given music, as well as also broader factors relating to regional or national influences (Hargreaves, North \& Tarrant, 2006). Some authors have analyzed the influence of social and cultural background from different perspectives (Miranda, Blais, et.al, 2013; Radocy \& Boyle, 2003; DeNora, 2000). In Spain, this relationship has been studied with samples of young adults and adolescents (Cremades, Lorenzo \& Herrera, 2010; Herrera, Cremades \& Lorenzo, 2010).

Hargreaves (1982) describes the typical behaviour of preschool-aged children known as open-earedness, which is characterized by the inclusion of diverse musical preferences from a wide spectrum. Thus, children tend to readily accept music of various styles, characters and expressive forms, and they are curious and accustomed to being open to all types of music. As Henriksson-Mcaulay \& Welch (2013) note, some babies even respond better to complex time structures than children over one year old, unless the latter have had rhythmic experiences during this first year, in that they retain this skill. Additionally, as occurs in individuals of various ages, the preference for one type of music can be subject to rapid change and strongly depends on the social context (Lamont \& Webb, 2010) and the opinions of others (Campbell-Meiklejohn, Bach, Roepstorff, Dolan, \& Frith, 2010). Henriksson-Mcaulay \& Welch, (2013) suggest that musical development is optimised if we experiment with a repertoire which includes varied musical elements and if music is listened to actively, either with participation such as movement or as the point of departure for improvising, for example. This fact assumes genuine importance in the area of education, and educational musical theories address the relevance of making decisions regarding the choice of musical repertoires and practices to support the development of children's identities. It appears that young children start to exhibit a preference for the music of their own culture at approximately two years of age during the period in which they start to develop specialized verbal processing. At this age, children first display a tendency to like simple songs with defined and predictable themes. Researchers cite ten years of age as a decisive moment for musical preferences (Levitin, 2006). Thus, music is one of the most important channels by which children and youths begin to define and express their identities. Musical identity is an important part of the cultural identity of individuals, and through it, the construction of musical preferences of children is fundamental to determining the identity and the position of the children in the social context. Typically, parents, teachers, musical educators and legislators recognize the value for artistic development, personal accomplishment and educational development of having children participate in musical experiences (O’Neill, 2001). Thus, family and school contexts have traditionally been the prime spaces in the transformation of musical knowledge (Young, 2008; Barret, 2013) and therefore in the formation of musical taste in young children (Tafuri, 2006). 
However, today technology and communication media make it possible to gain access to multiple cultural and musical expressions from diverse societies and allow different musical styles to reach the public immediately. This has led to a delocalisation of the learning context which determines the construction of preferences in terms of the music to which children listen, and therefore today it is more complex to ascertain where children learn music. All of this is a challenge for music teachers today, who have to prepare themselves to respond meaningfully to this change and need tools to help them understand their environment and take appropriate decisions that benefit their students (Author 2013; 2014). According to Sims (1986), teachers have traditionally played a crucial role in constructing and determining musical tastes. This factor gains importance within the music education process during childhood, where it is particularly essential to form an interest in listening to and reproducing high-quality artistic musical contents. Today, early childhood education teachers face a wide range of styles and musical products in a global society that includes multiple ways of listening to and producing music. It is important to contribute to forming children's aesthetic taste by presenting different activities in a way that not only facilitates student involvement but also meets individual needs (Author, 2013).

Students in early childhood education usually respond positively to musical stimuli, but this response varies according to the activity that implies active musical practice. Tafuri (2006), who has studied musical development in the inCanto project, noted that engaging in musical activities that revolve around three fundamental experiences, namely singing, performing and dancing (moving with the music), with a repertoire based first on the popular tradition complemented with the use of music from different styles and genres, leads to a greater development of children's musical abilities. The goal is to offer a sound bath (Tafuri, 2006, p. 147) as varied and pleasant as possible, so that the children are submerged in a simulating experience so that they soon memorise the melody, recognise the songs and express their preferences (Tafuri, 2006, p. 152). The author also states that the parents' contribution is crucial, when they repeat the activities done at school at home or show appreciation of their children's musical expressions. Denac (2008) also points out differences in the preferences and involvement of children in musical activities when they take place in school and family settings. According to Tafuri (2006), people are potentially musically gifted, but only when we experience positive, stimulating interaction with the atmosphere and education, among other factors like interest, do we fully develop our potential capacities. In her opinion, educators and parents are in charge of creating a stimulating educational context that favours the acquisition of musical abilities.

In addition, a number of studies include observations regarding the activities and environments in which children spend their time and the individuals with whom they interact in these contexts (Tudge, 2008). Barrett (2013) describes the central role and use of music in the lives of children and their families. We agree that although musical participation is a central part of these practices for many young children and their importance in early development has been recognized, few studies have investigated the ways in which children and their families use music in daily life (Barrett, 2013). Family is the primary social space and mediator between music and the human being, and there are many forms of contact with music that the family can facilitate.

De Vries (2009) has emphasised the lack of time that many parents have with respect to involvement in the musical life of their children and their trust in (i.e., their dependency on) on educational environments and recorded musical material (e.g., CDs and DVDs) to ensure the complete development of musical and artistic experience in young children. Young (2008) also investigates musical experiences in the home of children younger than two years and concludes that technological advances have generated changes in what is referred to as the nature of musical sources (e.g., television, CDs, videos, DVDs, cellular telephones, musical toys) and the nature of music that such children listen to and practice in the family context. 
In short, it is important to inquire into the evolution of musical experiences in terms of the kind of music preschool-aged children prefer. Likewise, we must also bear in mind the fact that the countless sources of music available today may determine these preferences. And finally, both families' and teachers' degree of knowledge about these preferences - which can be interpreted as their degree of involvement in them is equally important.

\section{Objectives}

The objectives of this study are:

- To find out which kind of songs five-year-old children cite as their favourites.

- To determine whether these children's preferred songs are learnt in or outside the classroom.

- To identify teachers' and families' degree of knowledge with children's favourite song.

\section{Methods}

\section{Sample}

This study was conducted in four Spanish autonomous communities. When choosing them, we took into account both geographic criteria (different geographic locations) and cultural criteria (even though they share certain features, there are differences in the cultural and linguistic traditions of each region). The Valencian Community and the Balearic Islands are located in the eastern part of the country, and along with Spanish, which is the official language throughout the entire country, they have a co-official language: Catalan. The autonomous community of the Basque Country (Euskadi) is located in the north of the Iberian Peninsula and also has a co-official language: Basque Language or Euskera. Despite their widespread use among the people, these co-official languages, both Catalan and Euskera, have not always been used as the language of instruction in formal education, and today their use is uneven. The fourth autonomous community included in this study is Cantabria, a monolingual region in the north of Spain. Furthermore, another distinctive feature when choosing the communities was the curricular framework of reference established by each community. "The government lays down the criteria for minimum teaching standards in $65 \%$ of the official curriculum, and each autonomous regional community, sets the remaining $35 \%$. The educational centres are responsible for implementing their chosen educational policies and the teachers are responsible for putting them into practice" (Díaz \& Giráldez, 2015, p. 263).

The sample consists of three groups of informants: children, families and teachers. The sample population includes a total of 286 five-year-old boys and girls, one family member who represents each child and 49 educators of the surveyed children from 26 schools in the autonomous communities.

\section{Data Collection}

The instrument used was a questionnaire designed ex professo for each group of informants and consisted of a series of dimensions, including the children's preferred song and dimensions linked to knowledge that the families and teachers of the children possess regarding this song. Prior to the study, a pilot study was performed in which a musical educator, six children and seven parents participated. The study contributed significantly to the preparation of the final instrument and the final design of the questions, of which some required closed responses and others open-ended responses. Additionally, for the methods to be as unified as possible, a performance protocol was constructed with guidelines and conditions to be 
considered by the interviewer [1]. The questions and dimensions shown in Table 1 were chosen for this text:

[Insert Table 1 here]

\section{Data Analysis}

As noted, different questionnaires were used to collect data on the preferred songs of the children. Each questionnaire used a different design depending on the type of respondent: the children, their families or their teachers. In investigating these three perspectives, this study followed the research of Ruiz Olabuénaga (2013) in its intention to compare and contrast significant similarities and differences regarding the same studied objective and to use these similarities and differences as quality-control criteria. In addition, to extend the investigation, this study also considered the geographic origin of the participants, i.e., their origin according to autonomous community. The study attempts to establish variables that contribute to contrasting the obtained data and that can therefore assure data quality.

The collected information was wide-ranging and required a careful ordering and systematization of categories to facilitate the discussion of the results and the explanation of the conclusions. This method of analysis is summarized in Table 2, which shows the origin of the initial questions (left column) and the song categories that emerged (middle and right columns). The corresponding codes indicate song origin and song type in a perspective that proceeds from general to specific. We previously established a structure to classify musical styles which at first distinguished traditional songs without a known author transmitted via oral tradition from popular songs with a known author (Author, 2013; 2014). Among those songs regarded as popular music, based on previous results we established a categorisation which allowed us to encompass some of the leading styles of popular music from the early decades of the $20^{\text {th }}$ century until today (Cripps, 1999). Furthermore, a category of songs considered popular children's songs (PI) also emerged, which includes those songs with a known composer which were composed specifically for children.

[Insert Table 2 here]

As previously mentioned, it was necessary to note the autonomous community of each respondent for each category (expressed in the following as AUT COM).

For the data analysis, SPSS software (version 22) was used. We calculated the Pearson Contingency Coefficient because the $\mathrm{X}^{2}$ does not have a range. This coefficient enables a more accurate interpretation as a $\mathrm{X}^{2}$ transformation, with a range between 0 and 1 .

\section{Results}

Based on a systematic review of these data, it was possible to perform a comprehensive analysis of the group of reviewed results. In addition, a partial analysis of these results was performed for each of the four autonomous communities included in the study, with the corresponding value that is derived from each of these focus areas. 
The results that are presented below have been analysed according to the type of learning context in which the children's preferred songs originate, that is, based on what has been learnt inside ("Formalschool") or outside school ("Informal-outside school"). In this regard, we should bear in mind that none of these contexts occurs in a pure state. Formal contexts are not always associated with schools just as informal contexts do not only exist outside schools. However, formality prevails inside schools and informality outside. From this vantage point, because this specific study refers to the formal context within schools, our goal is to focus on the aspects that essentially characterise this setting: the discourses between teachers and students and the information flows related to these discourses. Likewise, because we refer to the informal setting outside the school, we also allude to the kind of learning that stems from interaction with the family, the media, etc.

Based on these results, the level of knowledge of the teachers and families regarding the musical tastes of the children are presented.

According to an order consistent with the general objective of this study, the predominant learning contexts of the children's favourite songs are determined first. Second, the type of song that the children chose as their favourite is noted because the song type facilitates the determination of the emergent and predominant musical style. Next, the responses from the families and teachers regarding the styles that they believe the children like are considered.

\title{
a) Learning Context and Musical Taste
}

According to the values shown in Table 3, although the percentage is slightly higher for children who claim to have learnt their favourite song outside the school context (53.3\%), one can observe a remarkable balance between the two analysed learning contexts: "Formal-school" and "Informal-outside school".

Therefore, if the category AUT COM is combined with these results, one observes clearly differentiated patterns regarding the context in which children learnt their preferred songs $\left(X^{2}(6)=29.385(p=0.000)\right.$; $\mathrm{C}=0.306$ ) (Tables $3 \mathrm{a}, 3 \mathrm{~b}$ ). Thus, in the autonomous community of Basque Country, the context "Informal-outside school" clearly predominates ( $76 \%$ of the cases) compared with the Valencian Community (54.2\%) and Cantabria (50.8\%). In contrast, in the Balearic Islands, the learning context "Formal-school" prevails (60.5\% of the cases) (Table 3$)$.

\section{[Insert Table 3 here] [Insert Table 3a here] [Insert Table 3b here]}

To elaborate on the results, it is possible to establish that there are clearly differentiated patterns regarding the genre of the preferred song that children indicate ("Genre of preferred song according to children") combined with the learning context in which they access this knowledge ("Formal-school" or "Informaloutside school") $\left(\mathrm{X}^{2}(4)=310.678(\mathrm{p}=0.000) ; \mathrm{C}=0.722\right)$ (Tables $\left.4 \mathrm{a}, 4 \mathrm{~b}\right)$. Thus, one may confirm the following: $75.2 \%$ of the preferred songs by children learnt in the "Formal-school" context are traditional (T), whereas $83.6 \%$ of the songs preferred by children and learnt in the "Informal-outside school" context are popular (P) (Table 4).

\author{
[Insert Table 4 here] \\ [Insert Table 4a here] \\ [Insert Table 4b here]
}


In contrast, three subcategories are derived from the learning context "Informal-outside school": "Family" (Fa), "Media" (M) and "Friends" (Fr), which signify that the children learnt their favourite songs in the family context, through the mass media or under the influence of friends, respectively. Thus, from a total of $53.3 \%$, which includes the total of all the informal learning contexts studied (Table 4), $28.8 \%$ of the responses offered by children correspond to the context $\mathrm{M}$. This outcome corroborates the hypothesis that the mass media substantially influence the musical preferences of children. The context Fa occupies second place (15.8\%), and Fr ranks in last position (8.8\%) (Table 5).

If one considers the results obtained under these same parameters in terms of autonomous communities, one can observe that in the Valencian Community, Basque Country and the Balearic Islands, the context "Outside school", "Media" predominates as a channel for learning. However, in the autonomous community of Cantabria, the context "Family" predominates (Table 5). Therefore, we can reaffirm that clearly differentiated patterns exist with respect to the learning context of the preferred song of children as a function of the autonomous community $\left(\mathrm{X}^{2}(12)=53.448(\mathrm{p}=0.000) ; \mathrm{C}=0.397\right)$. Thus, this outcome confirms the meaning and appropriateness of this variable in the context of this study (Tables $5 \mathrm{a}, 5 \mathrm{~b}$ ).

[Insert Table 5 here]

[Insert Table 5a here]

[Insert Table 5b here]

\section{b) Musical Taste of Children}

As shown in Table 2, various subcategories appeared with respect to the "Genre of preferred song according to children". Thus, based on the total data (without first considering learning context or geographic origin), from the total of analysed responses regarding children's musical taste, it appears that $48.1 \%$ of the preferred songs are of the traditional type $(\mathrm{T})$, whereas $49.2 \%$ are popular $(\mathrm{P})$ which includes the sub-genres of popular children's songs, popular pop, popular Latino, popular disco, popular rock and other popular songs (Table 6).

However, if the results are analysed according to the "Autonomous community" variable, it appears that clearly differentiated patterns exist regarding the genre of children's preferred song $\left(\mathrm{X}^{2}(21)=63.132(\mathrm{p}\right.$ $=0.000) ; \mathrm{C}=0.426)($ Tables $6 \mathrm{a}, 6 \mathrm{~b})$. Based on the heterogeneity of the results in this case, one may conclude that the subcultures of musical taste that are derived from autonomous communities can be truly distinct from the taste subcultures derived from other sources.

$$
\begin{aligned}
& \text { [Insert Table } 6 \text { here] } \\
& \text { [Insert Table 6a here] } \\
& \text { [Insert Table } 6 \mathrm{~b} \text { here] }
\end{aligned}
$$

Based on responses obtained from children who stated that their favourite song had been learnt in school, $81.1 \%$ of those songs are traditional compared with popular songs (18.1\%). (popular children's songs, popular pop, popular disco, other popular songs) (Table 7). However, here, the combination of these data with the AUT COM variable does not yield different patterns. Thus, there is a notable confluence between these regions $\left(X^{2}(15)=29.398(p>0.05) ; C=0.434\right)($ Tables $7 a, 7 b)$. 
Learning Context: Formal-School

\author{
[Insert Table 7 here] \\ [Insert Table 7a here] \\ [Insert Table $7 \mathrm{~b}$ here]
}

If the learning context of the children's preferred song is "Outside school", the results are radically different, reversing the percentages. Thus, in this case, $76.8 \%$ of "Genre of preferred song according to children" learnt in this context are "Popular" (popular children's songs, popular pop, popular Latino, popular disco, popular rock and other popular songs) and only $22.4 \%$ are "Traditional" (Table 8 ).

Additionally, if these same results are combined with the "Autonomous community" variable, clearly differentiated patterns emerge in terms of "Genre of preferred song according to children" $\left(\mathrm{X}^{2}(21)=\right.$ 45.208 ( $\mathrm{p}<0.01$ ); $\mathrm{C}=0.479$ ) (Tables 8a, 8b). In the autonomous community of Basque Country and the Balearic Islands, the subgenre "Popular disco" predominates, with $50 \%$ and $36.7 \%$ of cases, respectively. In contrast, in the autonomous community of Cantabria, the genre "Traditional" predominates (40.6\%), and in the Valencian Community, the subgenre "Popular disco" accounts for $28.8 \%$ of the cases (Table $8)$.

Learning Context: Informal-Outside School

\author{
[Insert Table 8 here] \\ [Insert Table 8a here] \\ [Insert Table $8 \mathrm{~b}$ here]
}

Additionally, as shown in the two preceding tables, an analysis of the subgenres derived from the style "Popular" in both learning contexts reveals that in the environment "Formal-school" $13.4 \%$ of the children opt for "Popular children's" music (PC), followed by "Popular pop" (PP) (3.1\%). In third position, there is a tie between "Popular disco" (PD) and "Popular pop" (PP) (both 0.8\%) (Table 7).

Similarly, regarding the learning context "Informal-outside school", the results diverge. The option PD is the favourite (27.6\%), followed by PP and PC (both 16.4\%). In third position is PL (12.5\%), followed by PO (2.6\%). PR is the least valued (1.3\%) (Table 8$)$.

\title{
c) Musical Taste of Children according to their Families and Teachers (Knowledge of families and teachers regarding the musical preferences of children)
}

The children's, parents' and teachers' responses regarding the question on the children's favourite song were analysed with the goal of later determining whether the title of the song cited by children matched with the song cited by their families on the one hand and by their teachers on the other. The information obtained from the responses from the families and teachers regarding their beliefs about children's preferences largely coincides with the preferences that the children reported (67.4\%) (Table 9).

However, this agreement does not carry over when combined with the AUT COM variable. According to community, we find differentiated patterns $\left(X^{2}(6)=14.350(p<0.05) ; C=0.219\right)$ (Tables 9a, 9ab). Thus, in the case of the Balearic Islands, families and teachers know the musical preference of children at a rate 
of $75 \%$. Cantabria and the Valencian Community coincide at $69.8 \%$, thus converging with the data from the Balearic Islands. However, the openly discordant community is Basque Country, where the percentage is lower (48\%) (Table 9).

\author{
[Insert Table 9 here] \\ [Insert Table 9a here] \\ [Insert Table 9b here]
}

Regarding the level of teacher and parent knowledge of children's musical preferences as a function of learning context, clearly differentiated patterns are observed $\left(X^{2}(4)=80.445(p=0.000) ; C=0.469\right)$ (Tables 10a, 10b). The teachers recognize the children's musical taste at a rate of $89 \%$ compared with a clearly lower but not insignificant 52\% for the children's families (Table 10). Consequently, these data indicate that the distinction between the different learning contexts can be relevant and informative.

\author{
[Insert Table 10 here] \\ [Insert Table 10a here] \\ [Insert Table 10b here]
}

Based on the preceding procedure, we now focus on the results obtained by combining the variables "Learning context" and "Autonomous community". Regarding the formal learning context, it was noted (Table 10) that $89 \%$ of the teachers in the "Formal-school" context know the musical preferences of the children. As shown in the following table, the data continue in this vein in an approximate manner for each autonomous community, all of which display relatively similar values $\left(X^{2}(6)=10.958(p>00.5)\right.$; $=0.282)($ Tables $11 \mathrm{a}, 11 \mathrm{~b})$.

Learning Context: Formal-School

$$
\begin{aligned}
& \text { [Insert Table } 11 \text { here] } \\
& \text { [Insert Table 11a here] } \\
& \text { [Insert Table 11b here] }
\end{aligned}
$$

Regarding the learning context "Informal-outside school" (Table 10), the percentage of the families that know the musical preferences of the children decreases to 52\% (Table 10). As with the learning context "Formal-school", this outcome is largely affirmed when the autonomous community context is examined. In any case, as shown in the following table, the most striking exception is, again, the contrast between the Valencian Community, where for $65 \%$ of the cases the families know the preferences, and Basque Country $(36 \%)\left(X^{2}(6)=8.999(p>00.5) ; C=0.236\right)($ Tables 12a, 12b).

Learning Context: Informal-Outside School

\author{
[Insert Table 12 here] \\ [Insert Table 12a here] \\ [Insert Table 12b here]
}

\title{
Discussion and Conclusions
}


Based on the analysis of data collected, we were able to determine the children's favourite songs and whether they had learned these songs inside or outside school. At the same time, the results show that both teachers and families have considerable knowledge of children's musical preferences (Table 10). In the case of the teachers, this knowledge seems to indicate that the educational system, as represented by this group, is clearly connected to the children's musical reality. The fact that the traditional style is the most highly valued by students at school and that teachers are aware of these preferences confirms the teachers' high degree of awareness, which may bear a direct relationship with the repertoires that they choose, whose musical value fosters the acquisition of lessons targeted at developing the children's identity. All of this leads us to conclude that in the sample analysed, the choice of repertoire used by the teachers bore a significant influence on the formation of the children's musical taste.

At the same time, the awareness of children's musical preferences demonstrated by the families shows their interest in learning about the songs that their children like, or at least a high degree of communication among parents and children on this topic. We further note that more than half of the songs preferred by the children were learned in an informal context (Table 3). The family plays a crucial role in children's musical life outside the school, and therefore it bears a significant influence on the construction of children's musical taste, as reflected in the results.

We can find a connection between these results and the studies of Young (2008), Barret (2013) and Tafuri (2006), which identify family and school contexts as spaces where musical knowledge is transformed, as well as spaces that influence the formation of young children's musical taste.

However, we should point out the significant influence exerted by the audiovisual media in children, which can be seen in the data compiled in Table 5. The taste in the sub-genres of music expressed by the children outside and inside school is different, as indicated in Tables 7 and 8. On this point, it is clear that in this study disco, Latino and pop music emerged as musical sub-genres that the children learn via the media, which today offer musical diversity and easy access for anyone. Stemming from this cultural reality is the idea that learning is a complex web in which the different, varied musical styles and genres that children consume gradually shape a broader vision of the musical world around them. In this sense, the results corroborate the fact that the media like television bear an increasing influence on children's lives, even the youngest ones (Young, 2008), compared to the influence of the family milieu.

The use of the category that organises the data by autonomous community was shown to be relevant. The differences found between the results in each region indicate that when discussing musical preferences, the educational system is heterogeneous, at least on this topic. This can be explained by the differences that exist among the curricula in the four autonomous communities presented in the study. These curricula capture different cultural aspects of each region, including repertoires that show the linguistic diversity and unique musical traditions. On the other hand, based on the data obtained, the following are common in these autonomous communities: (1) the fact that children point out that within the school learning context, the vast majority of songs they cite as their favourites are traditional, and (2) the similarities in the percentages of teachers' and parents' knowledge on the children's musical preferences.

This study focuses on spotlighting the importance of singing and performing songs not only because it gets children involved in a way that is at once musical, social and personal, but also because by doing so we are communicating that making music is a socially esteemed activity, something that is being lost in $21^{\text {st }}$-century Western society (Henriksson-Mcaulay \& Welch, 2013). For this reason, it is essential to offer ongoing training with teaching options that include a wide range of musical activities, such as exploring songs, rhymes, rhythms, using the body by adding movement and sound-making objects. Changing the training of preschool teachers in this way is essential to empowering them to address a varied repertoire of musical preferences, as Young (2006) and Tafuri (2006) found, as it makes a major contribution to constructing musical preferences. Therefore, it is necessary for teachers to directly participate in the cultural education of their students (in both their pre-service education and their subsequent training) through rich, varied and meaningful experiences. These experiences should be capable of forging 
connections with the children's musical lives outside the school. In this way, the teachers can form their own aesthetic criteria for selecting the repertoires and musical activities that they will share with children.

\section{References}

Author(s) (2013; 2014), name deleted to maintain the integrity of the review process.

Barrett, M. S. (2013). "Vidas sonoras en y a través de la música: una investigación narrativa de la participación musical "cotidiana" de un niño pequeño" [Sound lives in and through music: A narrative study of the "everyday" musical participation of a young child]. In Díaz, M. \& Giráldez, A. (Comps.): Investigación cualitativa en educación musical. Barcelona. Graó, pp. 117-141.

Blood, A. J, \& Zatorre, R. J. (2001). Intensely pleasurable responses to music correlate with activity in brain regions implicated in reward and emotion. Proceedings of the National Academy of Sciences, 98(20), 11818-11823.

Bowles, C. L. (1998). Music activity preferences of elementary students. Journal of Research in Music Education, 46(2), 193-207.

Campbell-Meiklejohn, D. K, Bach, D. R, Roepstorff, A., Dolan, R. J, \& Frith, C. D. (2010). How the opinion of others affects our valuation of objects. Current Biology, 20(13), 1165-1170.

Cremades, Roberto, Lorenzo, Oswaldo, \& Herrera, Lucía. (2010). Musical tastes of secondary school students' with different cultural backgrounds: A study in the Spanish North African city of Melilla. Musicae Scientiae, 14(1), 121-141.

Cripps, C. (1999). La música popular en el siglo XX [Popular music in the 21st Century]. Madrid: Akal.

De Vries, P. (2009). Music at home with the under fives: what is happening? Early Child Development and Care, 179(4), 395-405.

Denac, O. (2008). A case study of preschool children's musical interests at home and at school. Early childhood education journal, 35(5), 439-444.

DeNora, T. (2000). Music in everyday life. Cambridge: Cambridge University Press.

Díaz, M. y Giráldez, A. (2015). Music Education in Spain: Beyond the Curriculum (259-280), en S. Figuereido, J. Soares y R.Fink Schambeck The preparation of Music Teachers: a global perspective, (pp. 259-280). Porto Alegre: ANPPOM.

Dobrota, S. \& Ercegovac, I. R. (2015). The relationship between music preferences of different mode and tempo and personality traits - implications for music pedagogy, Music Education Research, 17(2), 234-247.

Hargreaves, D. J. (1982). The development of aesthetic reactions to music. Psychology of Music, Special Issue, 51-54.

Hargreaves, D. (1998). Música y desarrollo psicológico [Developmental Psychology of Music]. Barcelona: Graó.

Hargreaves, D. J., North, A.C., \& Tarrant, M. (2006). Musical preference and taste in childhood and adolescence . In G.E. McPherson (Ed.), The child as musician. A handbook of musical developement, 135-154. Oxford University Press. 
Henriksson-Macaulay, L. \& Welch, G. (2015). The musical key to babies' cognitive and social development.International Journal of Birth and Parent Education 2(2):21-25.

Herrera, Lucía, Cremades, Roberto, \& Lorenzo, Oswaldo. (2010). Preferencias musicales de los estudiantes de Educación Secundaria Obligatoria: influencia de la educación formal e informal [Musical preferences in Compulsory Secondary Education students: Influence of formal and informal education]. Cultura y Educación, 22(1), 37-51.

Hui, W. V. (2009) Music listening preferences of Macau students, Music Education Research, 11(4), 485-500.

Lamont, A., \& Webb, R. (2010). Short-and long-term musical preferences: what makes a favourite piece of music? Psychology of Music, 38(2), 222-241.

Levitin, D. (2006). Tu cerebro y la música [Your brain and the music]. Barcelona, RBA.

Malbrán, S. (2010). Educación musical en la escuela infantil [Musical education in the infant school]. En M. Riaño y M. Díaz, Fundamentos musicales y didácticos en Educación Infantil, pp. 21-38. Santander: PUbliCan Ediciones. Universidad de Cantabria.

Malbrán, S., Díaz, M. y Mónaco, M. G. (2013). "Preferencias musicales infantiles. Visiones del maestro, los padres y los niños" [Early childhood musical preferences. Perspectives of the teacher, parents and children]. Actas de ECCoM, Nuestro Cuerpo en Nuestra Música, 1, 149-152.

Mithen, S. (2009) The Music Instinct. The evolutionary basis of musicality. Annals of the New York Academy of Sciences, 1169:3-12. doi: 10.1111/j.1749-6632.2009.04590.

North, A.C \& Hargreaves, D.J. (1997), Liking for musical styles. Musicae Scientiae, 1. 107-126.

O’Neill, S. (2001). Young people and music participation project: Practitioner report and summary of findings (Report by the Unit for the Study of Musical Skill and Development). Keele University. Retrieved from Youth, Music and Education website:

http://www.rymeyouth.com/young-music-participation-keele-university

Peery, J C., \& Peery, I. W. (1986). Effects of exposure to classical music on the musical preferences of preschool children. Journal of Research in Music Education, 34(1), 24-33.

Radocy, R. E., \& Boyle, J. D. (2003). Psychological foundations of musical behavior. Springfield, MO: Charles C. Thomas.

Ruiz O., J.I. (2012). Metodología de la investigación cualitativa [Methodology of the qualitative research]. Bilbao. Universidad de Deusto.

Schuckert, R. F, \& McDonald, R. L. (1968). An attempt to modify the musical preferences of preschool children. Journal of Research in Music Education, 16(1), 39-44.

Sims, W. L. (1986). The effect of high versus low teacher affect and passive versus active student activity during music listening on preschool children's attention, piece preference, time spent listening, and piece recognition. Journal of Research in Music Education, 34(3), 173-191.

Tafuri, J. (2006). ¿Se nace musical? Cómo promover las aptitudes musicales de los niños. [Infant Musicality: New Research for Educators and Parents]. Barcelona. Graó.

Tanner, J., Asbridge,M. y Wortley, S. (2008). Our Favorite Melodies: Musical Consumption and Teenage Lifestyles, The British Journal of Sociology, 59 117-144.

Temmerman, N. (2000). An investigation of the music activity preferences of pre-school children. British Journal of Music Education, 17(1), 51-60. 
Tudge, J. (2008). The Everyday Lives of Young Children: Culture, Class and Child.rearing in Diverse Societies. Nueva York. Cambridge University Press.

Welch, G.F. (2005) We are musical. International Journal of Music Education, 23(2):117-120. doi: $10.1177 / 0255761405052404$.

Young, S. (2008). Lullaby light shows: everyday musical experience among under-two-year-olds. International Journal of Music Education, 26: 33-46. doi:10.1177/0255761407085648

[1] The author of the questionnaire and survey protocol was Dr. Silvia Malbrán, who was a member of the research team that performed the following studies in Argentina and Spain: Malbrán, S., Díaz, M. \& Mónaco, M. (2013a). Preferencias Musicales Infantiles. Visiones del maestro, los padres y los niños. [Early childhood musical preferences. Perspective of the teacher, parents and children] EECOM. Buenos Aires; and Malbrán, S., Díaz, M., \& Mónaco, M. (2013b). Investigación en Educación Musical. Desarrollo de un protocolo de entrevista. [Musical education research. Developing an interview protocol] Conferencia Iberoamericana de ISME. Chile. In this study, only the results from the Spanish sample group are used. 
Table 1. Analysed dimensions and questions

\begin{tabular}{|l|l|l|l|}
\hline \multirow{2}{*}{ Dimensions } & \multicolumn{2}{|c|}{ Questions } \\
\cline { 2 - 4 } & \multicolumn{1}{|c|}{ Children } & \multicolumn{1}{|c|}{ Families } & \multicolumn{1}{c|}{ Teachers } \\
\hline $\begin{array}{l}\text { Favourite } \\
\text { song }\end{array}$ & $\begin{array}{l}\text { What is your } \\
\text { favourite song? }\end{array}$ & $\begin{array}{l}\text { What is your children's } \\
\text { favourite song? }\end{array}$ & $\begin{array}{l}\text { What the favourite songs are of the five-year- } \\
\text { old children in the class? }\end{array}$ \\
\hline $\begin{array}{l}\text { Learning } \\
\text { contexts }\end{array}$ & $\begin{array}{l}\text { Where did you } \\
\text { learn it? }\end{array}$ & $\begin{array}{l}\text { Do you know who } \\
\text { taught it to him/her? }\end{array}$ & $\begin{array}{l}\text { What songs do you teach in class to the five- } \\
\text { year-old children? }\end{array}$ \\
\hline
\end{tabular}


Table 2. Categories of emergent data analysis

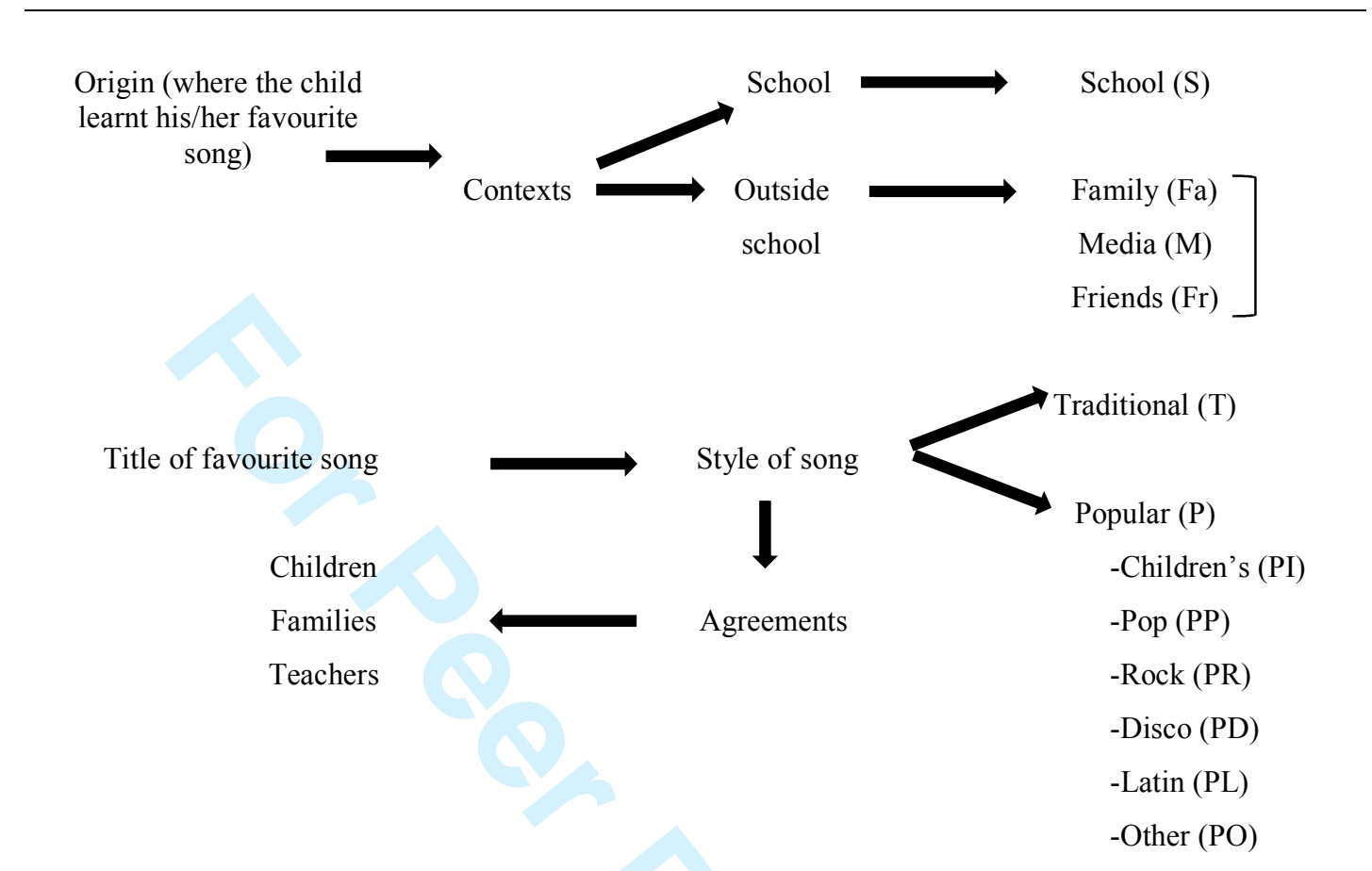


Table 3 . Learning context*autonomous community cross tabulation

\begin{tabular}{|c|c|c|c|c|c|c|}
\hline & & \multicolumn{4}{|c|}{ "Autonomous community } & \multirow[b]{2}{*}{ Total } \\
\hline & & Cantabria & $\begin{array}{l}\text { Valencian } \\
\text { Community }\end{array}$ & $\begin{array}{l}\text { Balearic } \\
\text { Islands }\end{array}$ & $\begin{array}{l}\text { Basque } \\
\text { Country }\end{array}$ & \\
\hline \multirow{6}{*}{$\begin{array}{l}\text { Learning } \\
\text { context }\end{array}$} & \multirow{2}{*}{ Formal-school } & 31 & 38 & 46 & 12 & 127 \\
\hline & & $49.20 \%$ & $39.60 \%$ & $60.50 \%$ & $24.00 \%$ & $44.60 \%$ \\
\hline & \multirow{2}{*}{$\begin{array}{l}\text { Informal- } \\
\text { outside school }\end{array}$} & 32 & 52 & 30 & 38 & 152 \\
\hline & & $50.80 \%$ & $54.20 \%$ & $39.50 \%$ & $76.00 \%$ & $53.30 \%$ \\
\hline & \multirow{2}{*}{$\begin{array}{l}\text { Does not } \\
\text { know/No } \\
\text { answer }\end{array}$} & 0 & 6 & 0 & 0 & 6 \\
\hline & & $0.00 \%$ & $6.30 \%$ & $0.00 \%$ & $0.00 \%$ & $2.10 \%$ \\
\hline \multirow{2}{*}{ Total } & & 63 & 96 & 76 & 50 & 285 \\
\hline & & $100.00 \%$ & $100.00 \%$ & $100.00 \%$ & $100.00 \%$ & $100.00 \%$ \\
\hline
\end{tabular}

Table 3(a). Chi-squared test

\begin{tabular}{lccc}
\hline \hline & Value & gl & $\begin{array}{c}\text { Asymptotic } \\
\text { sig. (2- } \\
\text { sided) }\end{array}$ \\
\hline $\begin{array}{l}\text { Pearson chi- } \\
\text { squared }\end{array}$ & $29.385^{\text {a }}$ & 6 & 0.000 \\
$\begin{array}{l}\text { Likelihood } \\
\text { ratio }\end{array}$ & 30.873 & 6 & 0.000 \\
$\begin{array}{l}\text { Linear by } \\
\text { linear } \\
\text { association }\end{array}$ & 0.068 & 1 & 0.794 \\
\hline $\begin{array}{l}\text { Number of } \\
\text { valid cases }\end{array}$ & & & \\
\hline \hline
\end{tabular}

a. Four boxes (33.3\%) expected a count less than five. The minimum expected count is 1.05 .

Table 3(b). Symmetrical measures

\begin{tabular}{llrr}
\hline \hline & Value & Approx. sig. \\
\hline $\begin{array}{l}\text { Nominal by } \\
\text { nominal }\end{array}$ & $\begin{array}{l}\text { Contingency } \\
\text { coefficient }\end{array}$ & 0.306 & 0.000 \\
Number of valid cases & \multicolumn{2}{c}{285} & \\
\hline \hline
\end{tabular}


Table 4. Learning context*genre of preferred song according to children (total) cross tabulation

\begin{tabular}{|c|c|c|c|c|c|}
\hline & & \multicolumn{3}{|c|}{$\begin{array}{l}\text { Genre of preferred song according to children } \\
\text { (total) }\end{array}$} & \multirow[b]{2}{*}{ Total } \\
\hline & & Traditional & Popular & $\begin{array}{c}\text { Does not } \\
\text { know/No } \\
\text { answer }\end{array}$ & \\
\hline \multirow{6}{*}{$\begin{array}{l}\text { Learning } \\
\text { context }\end{array}$} & \multirow{2}{*}{$\begin{array}{l}\text { Formal- } \\
\text { school }\end{array}$} & 103 & 23 & 1 & 127 \\
\hline & & $75.20 \%$ & $16.40 \%$ & $12.50 \%$ & $44.60 \%$ \\
\hline & \multirow{2}{*}{$\begin{array}{l}\text { Informal- } \\
\text { outside school }\end{array}$} & 34 & 117 & 1 & 152 \\
\hline & & $24.80 \%$ & $83.60 \%$ & $12.50 \%$ & $53.30 \%$ \\
\hline & \multirow{2}{*}{$\begin{array}{l}\text { Does not } \\
\text { know/No } \\
\text { answer }\end{array}$} & 0 & 0 & 6 & 6 \\
\hline & & $0.00 \%$ & $0.00 \%$ & $75.00 \%$ & $2.10 \%$ \\
\hline \multirow{2}{*}{ Total } & & 137 & 140 & 8 & 285 \\
\hline & & $100.00 \%$ & $100.00 \%$ & $100.00 \%$ & $100.00 \%$ \\
\hline
\end{tabular}

Table 4(a). Chi-squared test

\begin{tabular}{lccc}
\hline \hline & Value & gl & $\begin{array}{c}\text { Asymptotic } \\
\text { sig. (2- } \\
\text { sided) }\end{array}$ \\
\hline $\begin{array}{l}\text { Pearson chi- } \\
\text { squared }\end{array}$ & $310.678^{\mathrm{a}}$ & 4 & 0.000 \\
$\begin{array}{l}\text { Likelihood } \\
\text { Ratio }\end{array}$ & 152.358 & 4 & 0.000 \\
$\begin{array}{l}\text { Linear by } \\
\text { linear } \\
\text { association }\end{array}$ & 189.873 & 1 & 0.000 \\
\hline $\begin{array}{l}\text { Number of } \\
\text { valid cases }\end{array}$ & & & \\
\hline \hline
\end{tabular}

a. Five boxes (55.6\%) expected a count less than five. The minimum expected count is 0.17 .

Table 4(b). Symmetrical measures

\begin{tabular}{llrr}
\hline \hline & & Value & Approx. sig. \\
\hline $\begin{array}{l}\text { Nominal by } \\
\text { nominal }\end{array}$ & $\begin{array}{l}\text { Contingency } \\
\text { coefficient }\end{array}$ & 0.722 & 0.000 \\
Number of valid cases & 285 & \\
\hline \hline
\end{tabular}


Table 5. Who taught (according to the children)*autonomous community cross tabulation

\begin{tabular}{|c|c|c|c|c|c|c|}
\hline & & \multicolumn{4}{|c|}{ Autonomous community } & \multirow{2}{*}{ Total } \\
\hline & & Cantabria & $\begin{array}{l}\text { Valencian } \\
\text { Community }\end{array}$ & $\begin{array}{l}\text { Balearic } \\
\text { Islands }\end{array}$ & $\begin{array}{l}\text { Basque } \\
\text { Country }\end{array}$ & \\
\hline \multirow{10}{*}{$\begin{array}{l}\text { Who taught } \\
\text { (according to } \\
\text { the children) }\end{array}$} & \multirow{2}{*}{$\begin{array}{l}\text { Formal- } \\
\text { school }\end{array}$} & 31 & 38 & 46 & 12 & 127 \\
\hline & & $49.20 \%$ & $39.60 \%$ & $60.50 \%$ & $24.00 \%$ & $44.60 \%$ \\
\hline & \multirow{2}{*}{$\begin{array}{l}\text { Informal- } \\
\text { family }\end{array}$} & 15 & 10 & 10 & 10 & 45 \\
\hline & & $23.80 \%$ & $10.40 \%$ & $13.20 \%$ & $20.00 \%$ & $15.80 \%$ \\
\hline & \multirow{2}{*}{$\begin{array}{l}\text { Informal- } \\
\text { media }\end{array}$} & 13 & 37 & 17 & 15 & 82 \\
\hline & & $20.60 \%$ & $38.50 \%$ & $22.40 \%$ & $30.00 \%$ & $28.80 \%$ \\
\hline & \multirow{2}{*}{$\begin{array}{l}\text { Informal- } \\
\text { friends }\end{array}$} & 4 & 5 & 3 & 13 & 25 \\
\hline & & $6.30 \%$ & $5.20 \%$ & $3.90 \%$ & $26.00 \%$ & $8.80 \%$ \\
\hline & \multirow{2}{*}{$\begin{array}{l}\text { Does } \\
\text { know/No } \\
\text { answer }\end{array}$} & 0 & 6 & 0 & 0 & 6 \\
\hline & & $0.00 \%$ & $6.30 \%$ & $0.00 \%$ & $0.00 \%$ & $2.10 \%$ \\
\hline \multirow{2}{*}{ Total } & & 63 & 96 & 76 & 50 & 285 \\
\hline & & $100.00 \%$ & $100.00 \%$ & $100.00 \%$ & $100.00 \%$ & $100.00 \%$ \\
\hline
\end{tabular}

Table 5(a). Chi-squared test

\begin{tabular}{lccc}
\hline \hline & Value & gl & $\begin{array}{c}\text { Asymptotic } \\
\text { sig. }(2- \\
\text { sided) }\end{array}$ \\
\hline $\begin{array}{l}\text { Pearson chi- } \\
\text { squared }\end{array}$ & $53,448^{\mathrm{a}}$ & 12 & 0.000 \\
$\begin{array}{l}\text { Likelihood } \\
\text { ratio }\end{array}$ & 49,952 & 12 & 0.000 \\
$\begin{array}{l}\text { Linear by } \\
\text { linear } \\
\text { association }\end{array}$ & 1,764 & 1 & 0.184 \\
\hline $\begin{array}{l}\text { Number of } \\
\text { Valid Cases }\end{array}$ & & & \\
\hline \hline
\end{tabular}

a. Five boxes (25.0\%) expected a count less than five. The minimum expected count is 1.05 .

Table 5(b). Symmetrical measures

\begin{tabular}{llrr}
\hline \hline & Value & Approx. sig. \\
\hline $\begin{array}{l}\text { Nominal by } \\
\text { nominal }\end{array}$ & $\begin{array}{l}\text { Contingency } \\
\text { coefficient }\end{array}$ & 0.397 & 0.000 \\
Number of valid cases & 285 & \\
\hline \hline
\end{tabular}


Table 6. Genre of preferred song according to children*autonomous community cross tabulation

\begin{tabular}{|c|c|c|c|c|c|c|}
\hline & & & Autonomou & ommunity & & \\
\hline & & Cantabria & $\begin{array}{l}\text { Valencian } \\
\text { Community }\end{array}$ & $\begin{array}{l}\text { Balearic } \\
\text { Islands }\end{array}$ & $\begin{array}{l}\text { Basque } \\
\text { Country }\end{array}$ & Total \\
\hline \multirow{16}{*}{$\begin{array}{l}\text { Genres and } \\
\text { subgenres of } \\
\text { preferred } \\
\text { song } \\
\text { according to } \\
\text { children }\end{array}$} & \multirow{2}{*}{ Traditional } & 40 & 37 & 42 & 18 & 137 \\
\hline & & $63.50 \%$ & $38.50 \%$ & $55.30 \%$ & $36.00 \%$ & $48.10 \%$ \\
\hline & \multirow{2}{*}{$\begin{array}{l}\text { Popular } \\
\text { children's }\end{array}$} & 8 & 19 & 14 & 1 & 42 \\
\hline & & $12.70 \%$ & $19.80 \%$ & $18.40 \%$ & $2.00 \%$ & $14.70 \%$ \\
\hline & \multirow{2}{*}{ Popular pop } & 3 & 17 & 5 & 4 & 29 \\
\hline & & $4.80 \%$ & $17.70 \%$ & $6.60 \%$ & $8.00 \%$ & $10.20 \%$ \\
\hline & \multirow{2}{*}{ Popular Latin } & 7 & 6 & 3 & 3 & 19 \\
\hline & & $11.10 \%$ & $6.30 \%$ & $3.90 \%$ & $6.00 \%$ & $6.70 \%$ \\
\hline & \multirow{2}{*}{ Popular disco } & 4 & 9 & 11 & 19 & 43 \\
\hline & & $6.30 \%$ & $9.40 \%$ & $14.50 \%$ & $38.00 \%$ & $15.10 \%$ \\
\hline & \multirow{2}{*}{ Popular rock } & 1 & 0 & 0 & 1 & $\overline{2}$ \\
\hline & & $1.60 \%$ & $0.00 \%$ & $0.00 \%$ & $2.00 \%$ & $0.70 \%$ \\
\hline & \multirow{2}{*}{ Popular other } & 0 & 2 & 1 & 2 & 5 \\
\hline & & $0.00 \%$ & $2.10 \%$ & $1.30 \%$ & $4.00 \%$ & $1.80 \%$ \\
\hline & Does not & 0 & 6 & 0 & 2 & 8 \\
\hline & $\begin{array}{l}\text { know/No } \\
\text { answer }\end{array}$ & $0.00 \%$ & $6.30 \%$ & $0.00 \%$ & $4.00 \%$ & $2.80 \%$ \\
\hline \multirow{2}{*}{ Total } & & 63 & 96 & 76 & 50 & 285 \\
\hline & & $100.00 \%$ & $100.00 \%$ & $100.00 \%$ & $100.00 \%$ & $100.00 \%$ \\
\hline
\end{tabular}

Table 6(a). Chi-squared test

\begin{tabular}{lcrr}
\hline \hline & Value & gl & $\begin{array}{c}\text { Asymptotic } \\
\text { sig. }(2- \\
\text { sided) }\end{array}$ \\
\hline $\begin{array}{l}\text { Pearson chi- } \\
\text { squared }\end{array}$ & $63.132^{\mathrm{a}}$ & 21 & 0.000 \\
$\begin{array}{l}\text { Likelihood } \\
\text { ratio }\end{array}$ & 65.747 & 21 & 0.000 \\
$\begin{array}{l}\text { Linear by } \\
\text { linear } \\
\text { association }\end{array}$ & 10.477 & 1 & 0.001 \\
\hline $\begin{array}{l}\text { Number of } \\
\text { valid cases }\end{array}$ & 285 & & \\
\hline \hline
\end{tabular}

a. Fourteen boxes (43.8\%) expected a count less than five. The minimum expected count is 0.35 . 
Table 6(b). Symmetrical measures

\begin{tabular}{llcr}
\hline \hline & Value & Approx. sig. \\
\hline $\begin{array}{l}\text { Nominal by } \\
\text { nominal }\end{array}$ & $\begin{array}{l}\text { Contingency } \\
\text { coefficient }\end{array}$ & 0.426 & 0.000 \\
Number of valid cases & \multicolumn{2}{c}{285} & \\
\hline \hline
\end{tabular}


Table 7. Genre of preferred song according to children*autonomous community cross tabulation (learning context: "Formal-school")

\begin{tabular}{|c|c|c|c|c|c|c|}
\hline & & \multicolumn{4}{|c|}{ Autonomous community } & \multirow{2}{*}{ Total } \\
\hline & & Cantabria & $\begin{array}{l}\text { Valencian } \\
\text { Community }\end{array}$ & $\begin{array}{l}\text { Balearic } \\
\text { Islands }\end{array}$ & $\begin{array}{l}\text { Basque } \\
\text { Country }\end{array}$ & \\
\hline \multirow{12}{*}{$\begin{array}{l}\text { Genres and } \\
\text { subgenres of } \\
\text { preferred } \\
\text { song } \\
\text { according to } \\
\text { children }\end{array}$} & \multirow{2}{*}{ Traditional } & 27 & 29 & 37 & 10 & 103 \\
\hline & & $87.10 \%$ & $76.30 \%$ & $80.40 \%$ & $83.30 \%$ & $81.10 \%$ \\
\hline & \multirow{2}{*}{$\begin{array}{l}\text { Popular } \\
\text { children's }\end{array}$} & 2 & 6 & 9 & 0 & 17 \\
\hline & & $6.50 \%$ & $15.80 \%$ & $19.60 \%$ & $0.00 \%$ & $13.40 \%$ \\
\hline & \multirow{2}{*}{ Popular pop } & 2 & 2 & 0 & 0 & 4 \\
\hline & & $6.50 \%$ & $5.30 \%$ & $0.00 \%$ & $0.00 \%$ & $3.10 \%$ \\
\hline & \multirow{2}{*}{ Popular disco } & 0 & 1 & 0 & 0 & 1 \\
\hline & & $0.00 \%$ & $2.60 \%$ & $0.00 \%$ & $0.00 \%$ & $0.80 \%$ \\
\hline & \multirow{2}{*}{ Popular other } & 0 & 0 & 0 & 1 & 1 \\
\hline & & $0.00 \%$ & $0.00 \%$ & $0.00 \%$ & $8.30 \%$ & $0.80 \%$ \\
\hline & Does not & 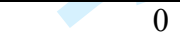 & 0 & 0 & 1 & 1 \\
\hline & $\begin{array}{l}\text { Know/No } \\
\text { answer }\end{array}$ & $0.00 \%$ & $0.00 \%$ & $0.00 \%$ & $8.30 \%$ & $0.80 \%$ \\
\hline \multirow{2}{*}{ Total } & & 31 & 38 & 46 & 12 & 127 \\
\hline & & $100.00 \%$ & $100.00 \%$ & $100.00 \%$ & $100.00 \%$ & $100.00 \%$ \\
\hline
\end{tabular}

Table 7(a). Table chi-squared test (learning context: "Formalschool")

\begin{tabular}{lcrr}
\hline \hline & Value & gl & $\begin{array}{c}\text { Asymptotic } \\
\text { sig. (2- } \\
\text { sided) }\end{array}$ \\
\hline $\begin{array}{l}\text { Pearson chi- } \\
\text { squared }\end{array}$ & $29.398^{\mathrm{a}}$ & 15 & 0.014 \\
$\begin{array}{l}\text { Likelihood } \\
\text { ratio }\end{array}$ & 22.920 & 15 & 0.086 \\
$\begin{array}{l}\text { Linear by } \\
\text { linear } \\
\text { association }\end{array}$ & 2.626 & 1 & 0.105 \\
\hline $\begin{array}{l}\text { Number of } \\
\text { valid cases }\end{array}$ & & & \\
\hline \hline
\end{tabular}

a. Eighteen boxes (75.0\%) expected a count less than five. The minimum expected count is 0.09 .

Table 7(b). Symmetrical measures (learning context: "Formalschool") 
Table 8. Genre of preferred song according to children*autonomous community cross tabulation (learning context: "Informal-outside school")

\begin{tabular}{|c|c|c|c|c|c|c|}
\hline & & & Autonomou & mmunity & & \\
\hline & & Cantabria & $\begin{array}{c}\text { Valencian } \\
\text { Community }\end{array}$ & $\begin{array}{l}\text { Balearic } \\
\text { Islands }\end{array}$ & $\begin{array}{l}\text { Basque } \\
\text { Country }\end{array}$ & I otal \\
\hline \multirow{16}{*}{$\begin{array}{l}\text { Genres and } \\
\text { subgenres of } \\
\text { preferred } \\
\text { song } \\
\text { according to } \\
\text { children }\end{array}$} & \multirow{2}{*}{ Traditional } & 13 & 8 & 5 & 8 & 34 \\
\hline & & $40.60 \%$ & $15.40 \%$ & $16.70 \%$ & $21.10 \%$ & $22.40 \%$ \\
\hline & \multirow{2}{*}{$\begin{array}{l}\text { Popular } \\
\text { Children's }\end{array}$} & 6 & 13 & 5 & 1 & 25 \\
\hline & & $18.80 \%$ & $25.00 \%$ & $16.70 \%$ & $2.60 \%$ & $16.40 \%$ \\
\hline & \multirow{2}{*}{ Popular pop } & 1 & 15 & 5 & 4 & 25 \\
\hline & & $3.10 \%$ & $28.80 \%$ & $16.70 \%$ & $10.50 \%$ & $16.40 \%$ \\
\hline & \multirow{2}{*}{ Popular Latin } & 7 & 6 & 3 & 3 & 19 \\
\hline & & $21.90 \%$ & $11.50 \%$ & $10.00 \%$ & $7.90 \%$ & $12.50 \%$ \\
\hline & \multirow{2}{*}{ Popular disco } & 4 & 8 & 11 & 19 & 42 \\
\hline & & $12.50 \%$ & $15.40 \%$ & $36.70 \%$ & $50.00 \%$ & $27.60 \%$ \\
\hline & \multirow{2}{*}{ Popular rock } & 1 & 0 & 0 & 1 & 2 \\
\hline & & $3.10 \%$ & $0.00 \%$ & $0.00 \%$ & $2.60 \%$ & $1.30 \%$ \\
\hline & \multirow{2}{*}{ Popular other } & 0 & 2 & 1 & 1 & 4 \\
\hline & & $0.00 \%$ & $3.80 \%$ & $3.30 \%$ & $2.60 \%$ & $2.60 \%$ \\
\hline & Does not & 0 & 0 & 0 & 1 & 1 \\
\hline & $\begin{array}{l}\text { know/No } \\
\text { answer }\end{array}$ & $0.00 \%$ & $0.00 \%$ & $0.00 \%$ & $2.60 \%$ & $0.70 \%$ \\
\hline \multirow{2}{*}{ Total } & & 32 & 52 & 30 & 38 & 152 \\
\hline & & $100.00 \%$ & $100.00 \%$ & $100.00 \%$ & $100.00 \%$ & $100.00 \%$ \\
\hline
\end{tabular}

Table 8(a). Chi-squared test (learning context: "Informal-outside school")

\begin{tabular}{lcrr}
\hline \hline & Value & gl & $\begin{array}{c}\text { Asymptotic } \\
\text { sig. (2- } \\
\text { sided) }\end{array}$ \\
\hline $\begin{array}{l}\text { Pearson chi- } \\
\text { squared }\end{array}$ & $45.208^{\mathrm{a}}$ & 21 & 0.002 \\
$\begin{array}{l}\text { Likelihood } \\
\text { ratio }\end{array}$ & 48.338 & 21 & 0.001 \\
$\begin{array}{l}\text { Linear by } \\
\text { linear } \\
\text { association }\end{array}$ & 12.958 & & 0.000 \\
\hline $\begin{array}{l}\text { Number of } \\
\text { valid cases }\end{array}$ & 152 & & \\
\hline \hline
\end{tabular}


a. Seventeen boxes (53.1\%) expected a count less than five. The minimum expected count is 0.20 .

Table 8(b). Symmetrical measures (learning context: "Informaloutside school")

\begin{tabular}{|c|c|c|}
\hline & Value & Approx. sig. \\
\hline $\begin{array}{ll}\text { Nominal by } & \text { Contingency } \\
\text { nominal } & \text { coefficient }\end{array}$ & 0.479 & 0.002 \\
\hline Number of valid cases & 152 & \\
\hline
\end{tabular}

16

17

18

19

20

21

22

23

24

25

26

27

28

29

30

31

32

33

34

35

36

37

38

39

40

41

42

43

44

45

46

47

48

49

50

51

52

53

54

55

56

57

58

59

60 
Table 9. Knowledge of musical preference of children*autonomous community cross tabulation

\begin{tabular}{|c|c|c|c|c|c|c|}
\hline & & \multicolumn{4}{|c|}{ Autonomous community } & \multirow{2}{*}{ Total } \\
\hline & & Cantabria & $\begin{array}{l}\text { Valencian } \\
\text { Community }\end{array}$ & $\begin{array}{l}\text { Balearic } \\
\text { Islands }\end{array}$ & $\begin{array}{l}\text { Basque } \\
\text { Country }\end{array}$ & \\
\hline \multirow{6}{*}{$\begin{array}{l}\text { Knowledge of } \\
\text { musical } \\
\text { preference of } \\
\text { children }\end{array}$} & \multirow{2}{*}{ Knows } & 44 & 67 & 57 & 24 & 192 \\
\hline & & $69.80 \%$ & $69.80 \%$ & $75.00 \%$ & $48.00 \%$ & $67.40 \%$ \\
\hline & \multirow{2}{*}{$\begin{array}{l}\text { Does not } \\
\text { know }\end{array}$} & 12 & 15 & 12 & 11 & 50 \\
\hline & & $19.00 \%$ & $15.60 \%$ & $15.80 \%$ & $22.00 \%$ & $17.50 \%$ \\
\hline & \multirow{2}{*}{$\begin{array}{l}\text { Does not } \\
\text { know/No } \\
\text { answer }\end{array}$} & 7 & 14 & 7 & 15 & 43 \\
\hline & & $11.10 \%$ & $14.60 \%$ & $9.20 \%$ & $30.00 \%$ & $15.10 \%$ \\
\hline \multirow{2}{*}{ Total } & & 63 & 96 & 76 & 50 & 285 \\
\hline & & $100.00 \%$ & $100.00 \%$ & $100.00 \%$ & $100.00 \%$ & $100.00 \%$ \\
\hline
\end{tabular}

Table 9(a). Chi-squared test

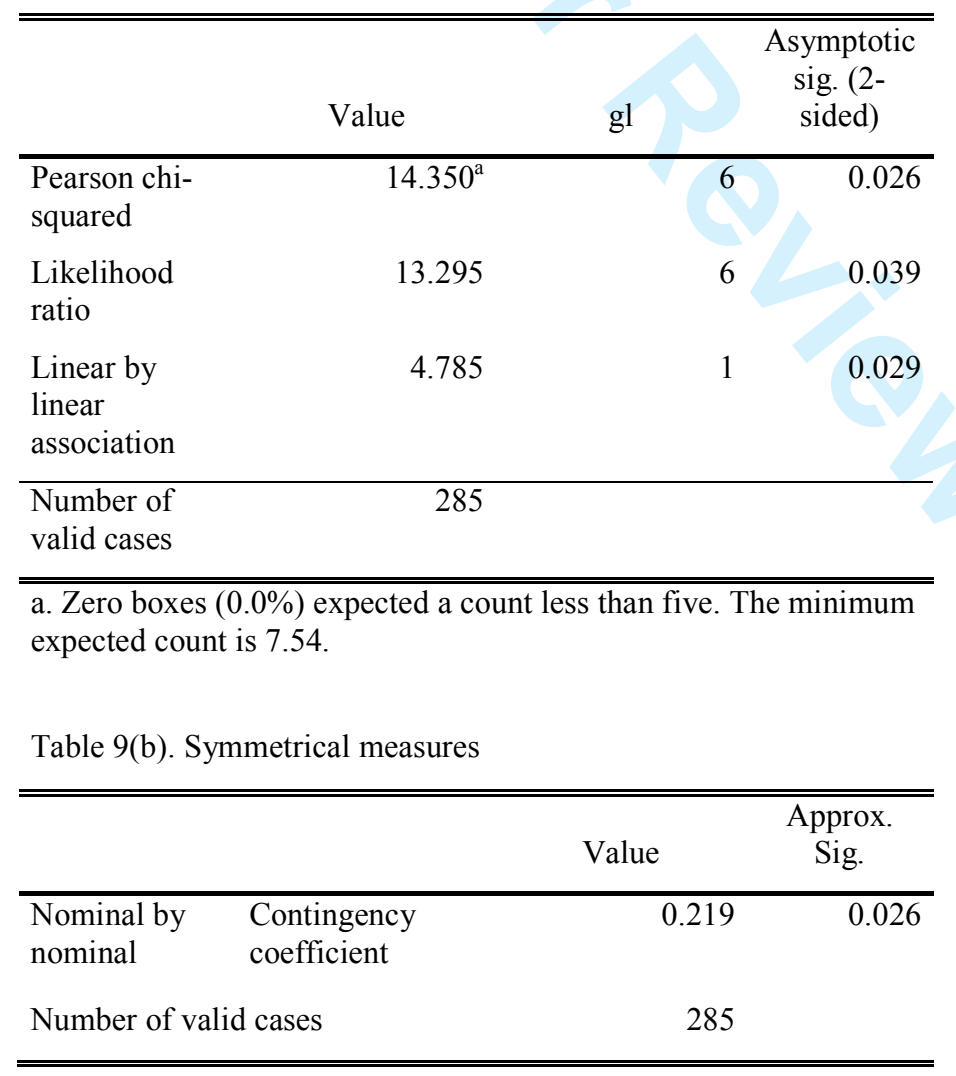


Table 10. Learning context*knowledge of musical preference of children cross tabulation

\begin{tabular}{|c|c|c|c|c|c|}
\hline & & \multicolumn{3}{|c|}{ Knowledge of musical preference of children } & \multirow[b]{2}{*}{ Total } \\
\hline & & Knows & $\begin{array}{c}\text { Does not } \\
\text { know }\end{array}$ & $\begin{array}{c}\text { Does not } \\
\text { know/No } \\
\text { answer }\end{array}$ & \\
\hline \multirow{9}{*}{$\begin{array}{l}\text { Learning } \\
\text { context }\end{array}$} & \multirow{3}{*}{$\begin{array}{l}\text { Formal- } \\
\text { school / } \\
\text { Teachers }\end{array}$} & 113 & 13 & 1 & 127 \\
\hline & & $89.00 \%$ & $10.20 \%$ & $0.80 \%$ & $100.00 \%$ \\
\hline & & $58.90 \%$ & $26.00 \%$ & $2.30 \%$ & $44.60 \%$ \\
\hline & \multirow{3}{*}{$\begin{array}{l}\text { Informal- } \\
\text { outside school } \\
\text { / Parents }\end{array}$} & 79 & 37 & 36 & 152 \\
\hline & & $52.00 \%$ & $24.30 \%$ & $23.70 \%$ & $100.00 \%$ \\
\hline & & $41.10 \%$ & $74.00 \%$ & $83.70 \%$ & $53.30 \%$ \\
\hline & \multirow{3}{*}{$\begin{array}{l}\text { Does not } \\
\text { know/No } \\
\text { answer }\end{array}$} & 0 & 0 & 6 & 6 \\
\hline & & $0.00 \%$ & $0.00 \%$ & $100.00 \%$ & $100.00 \%$ \\
\hline & & $0.00 \%$ & $0.00 \%$ & $14.00 \%$ & $2.10 \%$ \\
\hline \multirow{3}{*}{ Total } & & 192 & 50 & 43 & 285 \\
\hline & & $67.40 \%$ & $17.50 \%$ & $15.10 \%$ & $100.00 \%$ \\
\hline & & $100.00 \%$ & $100.00 \%$ & $100.00 \%$ & $100.00 \%$ \\
\hline
\end{tabular}

Table 10(a). Chi-squared test

\begin{tabular}{lcrr}
\hline \hline & Value & gl & $\begin{array}{c}\text { Asymptotic } \\
\text { sig. (2- } \\
\text { sided) }\end{array}$ \\
\hline $\begin{array}{l}\text { Pearson chi- } \\
\text { squared }\end{array}$ & $80.445^{\mathrm{a}}$ & 4 & 0.000 \\
$\begin{array}{l}\text { Likelihood } \\
\text { ratio }\end{array}$ & 81.364 & & 0.000 \\
$\begin{array}{l}\text { Linear by } \\
\text { linear } \\
\text { association }\end{array}$ & 59.485 & & 0.000 \\
\hline $\begin{array}{l}\text { Number of } \\
\text { valid cases }\end{array}$ & & & \\
\hline \hline
\end{tabular}

a. Three boxes (33.3\%) expected a count less than five. The minimum expected count is 0.91 .

Table 10(b). Symmetrical measures

\begin{tabular}{llrr}
\hline \hline & Value & Approx. sig. \\
\hline $\begin{array}{l}\text { Nominal by } \\
\text { nominal }\end{array}$ & $\begin{array}{l}\text { Contingency } \\
\text { coefficient }\end{array}$ & 0.469 & 0.000 \\
Number of valid cases & 285 & \\
\hline \hline
\end{tabular}




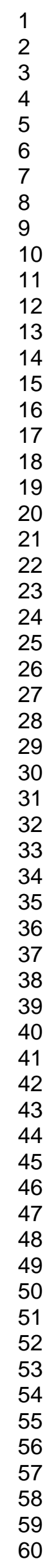

URL: http://mc.manuscriptcentral.com/cmue 
Table 11. Knowledge of musical preference of children*autonomous community cross tabulation (learning context: "Formal-school" / Teachers)

\begin{tabular}{|c|c|c|c|c|c|c|}
\hline & & \multicolumn{4}{|c|}{ Autonomous community } & \multirow{2}{*}{ Total } \\
\hline & & Cantabria & $\begin{array}{l}\text { Valencian } \\
\text { Community }\end{array}$ & $\begin{array}{l}\text { Balearic } \\
\text { Islands }\end{array}$ & $\begin{array}{l}\text { Basque } \\
\text { Country }\end{array}$ & \\
\hline \multirow{6}{*}{$\begin{array}{l}\text { Knowledge of } \\
\text { musical } \\
\text { preference of } \\
\text { children }\end{array}$} & & 27 & 33 & 43 & 10 & 113 \\
\hline & Knows & $87.10 \%$ & $86.80 \%$ & $93.50 \%$ & $83.30 \%$ & $89.00 \%$ \\
\hline & Does not & 4 & 5 & 3 & 1 & 13 \\
\hline & know & $12.90 \%$ & $13.20 \%$ & $6.50 \%$ & $8.30 \%$ & $10.20 \%$ \\
\hline & Does not & 0 & 0 & 0 & 1 & 1 \\
\hline & $\begin{array}{l}\text { know/No } \\
\text { answer }\end{array}$ & $0.00 \%$ & $0.00 \%$ & $0.00 \%$ & $8.30 \%$ & $0.80 \%$ \\
\hline \multirow{2}{*}{ Total } & & 31 & 38 & 46 & 12 & 127 \\
\hline & & $100.00 \%$ & $100.00 \%$ & $100.00 \%$ & $100.00 \%$ & $100.00 \%$ \\
\hline
\end{tabular}

Table 11(a). Chi-squared test (learning context: "Formal-school" / Teachers)

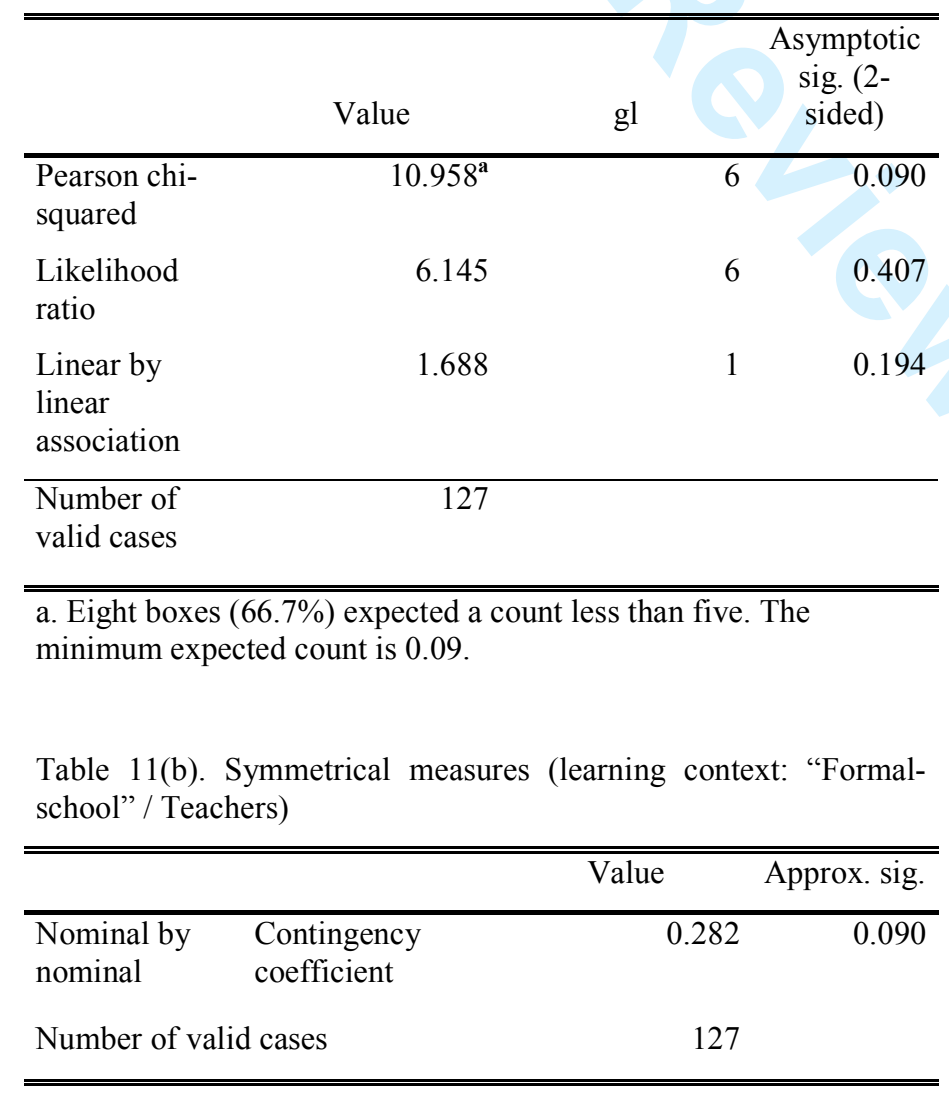




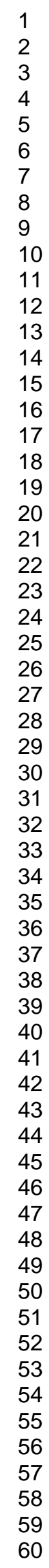
7 10 11 2 13 14 15

16

17

19

20

22

23

25

26

27

29

32

33

34

35

36

37

39

40

41

42

44

45

46

47

48

50

51

53

54

55

57

58

59

60 
Table 12. Knowledge of musical preference of children*autonomous community cross tabulation (learning context: "Informal-outside school" / Parents)

\begin{tabular}{|c|c|c|c|c|c|c|}
\hline & & \multicolumn{4}{|c|}{ Autonomous community } & \multirow{2}{*}{ Total } \\
\hline & & Cantabria & $\begin{array}{l}\text { Valencian } \\
\text { Community }\end{array}$ & $\begin{array}{c}\text { Balearic } \\
\text { Islands }\end{array}$ & $\begin{array}{l}\text { Basque } \\
\text { Country }\end{array}$ & \\
\hline \multirow{6}{*}{$\begin{array}{l}\text { Knowledge of } \\
\text { musical } \\
\text { preference of } \\
\text { children }\end{array}$} & & 17 & 34 & 14 & 14 & 79 \\
\hline & Knows & $53.10 \%$ & $65.40 \%$ & $46.70 \%$ & $36.80 \%$ & $52.00 \%$ \\
\hline & Does not & 8 & 10 & 9 & 10 & 37 \\
\hline & know & $25.00 \%$ & $19.20 \%$ & $30.00 \%$ & $26.30 \%$ & $24.30 \%$ \\
\hline & Does not & 7 & 8 & 7 & 14 & 36 \\
\hline & $\begin{array}{l}\text { know/No } \\
\text { answer }\end{array}$ & $21.90 \%$ & $15.40 \%$ & $23.30 \%$ & $36.80 \%$ & $23.70 \%$ \\
\hline \multirow{2}{*}{ Total } & & 32 & 52 & 30 & 38 & 152 \\
\hline & & $100.00 \%$ & $100.00 \%$ & $100.00 \%$ & $100.00 \%$ & $100.00 \%$ \\
\hline
\end{tabular}

Table 12(a). Chi-squared test (learning context: "Informal-outside school" / Parents)

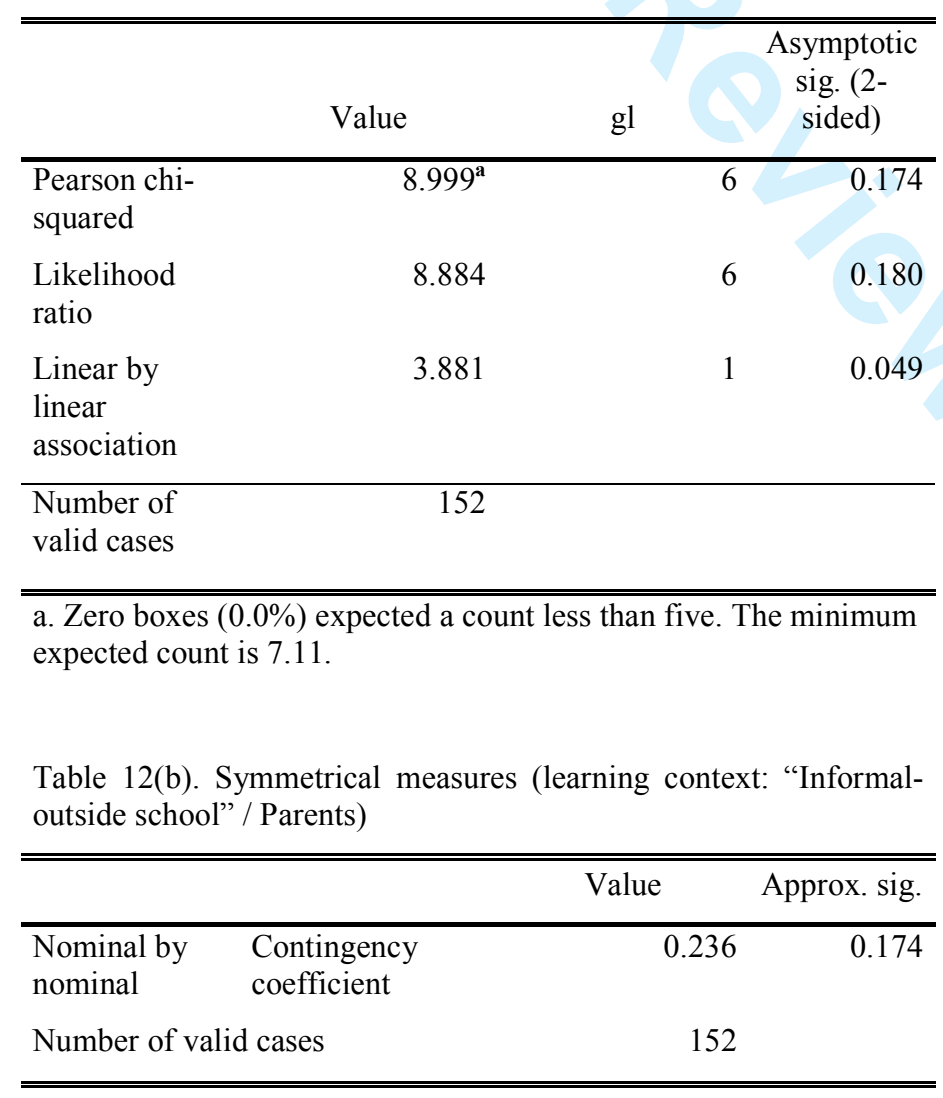




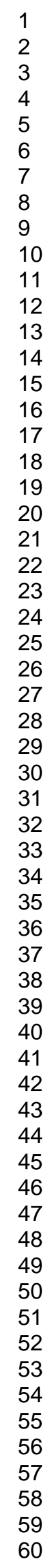

1 23 5

37 38 39 41 42 44 45 46 7 48 50 51 